\title{
MAKNA SIMBOLIK TABU PERTUNJUKAN WAYANG KULIT DI PURBALINGGA, KARESIDENAN BANYUMAS, JAWA TENGAH
}

\author{
Sugeng Priyadi \\ Jurusan Pedalangan, Fakultas Seni Pertunjukan, \\ Institut Seni Indonesia Denpasar, Indonesia
}

\begin{abstract}
The taboo of leather puppet show in the rural community of Purbalingga shows a plurality of socio-culture laying on the puppet myth that has changed into local legend. The myth said that Purbalingga is the region of Kurawa. This belief leads to such social conflicts as cultural conflict, marriage conflict, spiritual conflict, and ethic conflict. These conflicts are so obviously seen in the area. The cultural conflicts have triggered the taboo of puppet show in the rural area of Purbalingga. The taboo can be perceived as the phenomena of 1) a violence ang regret to the local puppet legend making some story sacral and taboo to perform, 2) a knight ascetics having some different meanings. Arjuna lived as an ascetic to get a weapon and a glory in the battle, while Yudhistira did that to achieve ultimate nobility in life, and 3) an ethic violation concerned with the characters, of puppet in the legend of Ramayana and Mahabarata, that are regarded as the ancestors of Purbalingga community.
\end{abstract}

Keywords: Tabu pertunjukan wayang kulit dan sakral.

Tabu pertunjukan wayang kulit di perdesaan Purbalingga, Karesidenan Banyumas banyak ditemukan. Hal itu menjadi mitos yang identik dengan daerah aliran Sungai Serayu-Klawing-Pekacangan. Oleh masyarakat setempat mitos wayang dipercaya sungguh-sungguh terjadi di DAS Serayu yang selalu terkait dengan keberadaan Dataran Tinggi Dieng yang juga di sana ditemukan gugusan percandian yang dikaitkan dengan mitos wayang, bahkan perang Baratayuda pun terjadi di daerah Karesidenan Banyumas sehingga lakon Baratayuda disakralkan dan selanjutnya ditabukan oleh masyarakat lokal.

Tulisan ini merupakan sebagian dari hasil penelitian tabu pertunjukan wayang kulit di perdesaan Purbalingga yang ditempuh dengan metode folklor (wawancara, klasifikasi, dan verifikasi) (Danandjaja,1985:1-21) dan 
metode sejarah (heuristik, kritik, interpretasi, dan historiografi) (Notosusanto, 1978:35-43). Metode folklor ditempuh dengan pertimbangan karena sumber data berbentuk folklor lisan yang diwariskan oleh masyarakat setempat. Selanjutnya, bahan-bahan folklor dipakai sebagai sumber sejarah, khususnya dalam rangka penulisan sejarah kebudayaan (Kartodirdjo, 1986) di tingkat lokal.

\section{CERITA SAKRAL: ANTARA KEKERASAN DENGAN PENYESALAN}

Perang Baratayuda dengan segala kekerasannya telah memakan korban yang cukup besar. Tidak hanya para prajurit dan pengikut kedua belah pihak yang bertikai, tetapi juga yang paling tragis adalah keluarga Kurawa yang tumpas atau habis tanpa tersisa. Mereka yang disebut seratus Kurawa itu meliputi: 1) Duryudana, 2) Dussasana, 3) Dussaha, 4) Dusala, 5) Jalasanda, 6) Sama, 7) Saha, 8) Winda, 9) Anuwinda, 10) Durdarsa, 11) Subahu, 12) Durpadarsana, 13) Durmasana, 14) Durmuka, 15) Duskarna, 16) Karna, 17) Wiwingsati, 18) Wikarna, 19) Sala, 20) Satwa, 21) Sulocana, 22) Citra, 23) Upacitra, 24) Citraksa, 25) Carucitra, 26) Sarasana, 27) Durmada, 28) Durwigaha, 29) Wiwitsuh, 30) Wikatanana, 31) Urnanaba, 32) Sunaba, 33) Nandaka, 34) Upanandaka, 35) Citrawana, 36) Cutrawarman, 37) Suwarman, 38) Durwilotana, 39) Ayobau, 40) Mahabau, 41) Citraga, 42) Citrakundala, 43) Bimawega, 44) Bimawala, 45) Balaki, 46) Balawardana, 47) Ugayuda, 48) Bima, 49) Kanakaya, 50) Dredayuda, 51) Dredawarman, 52) Dredaksattra, 53) Somakirti, 54) Anudara, 55) Dredasanda, 56) Jarasanda, 57) Satyasanda, 58) Sanda, 59) Subatsa, 60) Ugrasrawa, 61) Ugrasena, 62) Senani, 63) Durparajaya, 64) Aparajita, 65) Kundasayin, 66) Wisalaksa, 67) Doradara, 68) Dretahasta, 69) Suhasta, 70) Watawega, 71) Suwarcas, 72) Adityaketu, 73) Wahwasin, 74) Nagadatta, 75) Agrayayin, 76) Kawacin, 77) Kratana, 78) Kunda, 79) Kundadara, 80) Danurdara, 81) Ugra, 82) Bimaratta, 83) Wirabau, 84) Alolupa, 85) Abaya, 86) Rudrakarman, 87) Dredaratta, 88) Anadresya, 89) Kundabedin, 90) Wirawi, 91) Dirgalocana, 92) Pramatta, 93) Pramatti, 94) Dirgaroma, 95) Dirgabau, 96) Mahabau (Wirabau ?), 97) Wiyudarsus, 98) Kanakadaya, 99) Kundasin, dan 100) Dursilawati (Toeriman, 1984:5; bdk. Setyowibowo, 1990:120122).

Sementara itu di dalam dunia pedalangan pada umumnya, tokoh Kurawa yang dikenal hanya 22 orang, yaitu: 1) Bogadenta, 2) Bomawikata, 3) Citraksa, 4) Citraksi, 5) Citraboma, 6) Citrayuda, 7) Carucitra, 8) Duryudana (Kurupati atau Suyudana), 9) Dursasana, 10) Durmuka, 11) Durmagati, 12) Durjaya, 13) Durgempo, 14) Gardapura, 15) Gardapati, 16) Kartamarma, 17) Kartadenta, 18) Naranurwinda, 19) Surtayu, 20) Surtayuda, 21) Wikataboma, dan 22) Windadini (Setyawibowo, 1990:39-40). Meskipun 
yang dikisahkan tidak seratus orang yang terbunuh, tetapi ketika Duryudana berhadapan dengan Bima, keluarga Kurawa tinggal dua orang yang hidup, yakni Duryudana dan Kartamarma. Hal itu diceritakan dalam Perang Baratayuda versi Jawa yang meliputi 12 babak yang dipergelarkan di Keraton Yogyakarta selama setahun, yaitu: 1) Baratajuda Babak Ke-1 (Pendahuluan) Kalabendana Lena (Tjermatjarita 1958a), 2) Baratajuda Babak Ke-2 (Pendahuluan) Kresna Gugah (Tjermatjarita, 1958b), 3) Baratajuda Babak Ke-3 (Djabelan) Kresna Duta (Tjermatjarita, 1958c), 4) Baratajuda Babak Ke-4 Seta Gugur (Tjermatjarita, 1958d), (5) Baratajuda Babak Ke-5 Bogadenta Gugur (Tjermatjarita, 1958e), (6) Baratajuda Babak Ke-6 Randjapan (Renyuhan) (Tjermatjarita, 1958f), (7) Baratajuda Babak VII Burisrawa Gugur Atau Timpalan (Tjermatjarita 1958g), (8) Baratajuda Babak Ke-8 Suluhan (Gatutkatja Gugur (Tjermatjarita 1958h), (9) Baratajuda Babak Ke-9 Karna Tanding (Tjermatjarita 1958i), (10) Baratajuda Babak Ke-10 Rubuhan (Sujudana Gugur) (Tjermatjarita 1958j), (11) Baratajuda Babak Ke-11 Lahirnya Parikesit (Tjermatjarita, 1958k) (12) Baratajuda Babak Ke-12 Djumenengan (Lakon Sesudah Baratajuda) (Tjermatjarita, 19581).

Tokoh-tokoh yang menjadi korban Baratayuda, baik ketika perang belum dimulai, ketika peristiwa itu berlangsung, maupun ketika Baratayuda telah usai, memakan korban yang menyedihkan. Meskipun lima orang Pandawa lolos dari kematian, tetapi mereka banyak kehilangan sanaksaudara dan anak-anak mereka. Babak I yang menjadi korban adalah Kalabendana yang terbunuh oleh Gatotkaca karena ia membocorkan Abimanyu yang kawin dengan putri Wirata, Dewi Uttari, kepada Siti Sundari. Karena marah, Gatotkaca menjadi mata gelap dan membunuh pamannya sendiri. Babak II korbannya adalah Antareja yang sudah siap turun laga, tetapi ia tidak mempunyai musuh. Para dewa sebenarnya sudah menetapkan bahwa Antareja akan dihadapkan dengan Baladewa. Namun, Kresna meminta ketetapan itu dibatalkan, maka dewa menyuruh Kresna untuk menyingkirkan mereka berdua. Prabu Baladewa disingkirkan ke Grojogan Sewu untuk melakukan tapa, sedangkan Antareja menjilat bekas telapak kakinya sendiri tanpa disadarinya hingga tewas. Babak III korbannya meliputi Drestarastra dan Dewi Gendari, serta Wisanggeni. Kedua orang tua Kurawa itu tewas karena Kresna melakukan tiwikrama sehingga ada tembok yang roboh dan menimpa Drestarastra dan Dewi Gendari. Kematian kedua orang tua Kurawa itu murni versi Jawa karena pada versi Mahabharata, Dewi Gendari ketika Perang Baratayuda berakhir ia mengutuk Kresna akan mengalami kematian yang sangat mengerikan dan keluarga Yadawa tumpas seperti Kurawa. Sementara itu, Wisanggeni berpulang ke alam keabadian dengan penuh kesadaran karena ia dinasihatkan oleh Sang Hyang Wenang. Jika Wisanggeni terlibat pada Perang Baratayuda, maka Pandawa akan menemui kekalahan, sebaliknya jika ia tidak terlibat, maka Pandawa akan 
memperoleh kemenangan. Babak IV yang jatuh sebagai korban adalah Bambang Irawan (terbunuh ketika akan bergabung dengan keluarga Pandawa), Utara dan Wratsangka (senapati Pandawa yang pertama-tama gugur), Rukmarata (putra mahkota Mandaraka), Resi Seta (senapati Pandawa), dan Resi Bisma (senapati Kurawa). Babak $V$ mengisahkan tewasnya senapati Kurawa yang meliputi Prabu Bogadenta, Kertipeya, dan Murdaningsih, sedangkan dari pihak keluarga Pandawa, Antasena juga kembali ke alam keabadian yang kasusnya tidak berbeda dengan Wisanggeni. Pada Babak VI, banyak korban yang jatuh, baik dari pihak Kurawa maupun Pandawa. Korban pihak Kurawa meliputi Prabu Gardapati, Prabu Wresaya, Sarojakusuma (Sarojabinangun atau Lesmana Mandrakumara, putra mahkota Astina), Wisakusuma (putra Jayajatra), dan Jayajatra. Korban pihak Pandawa adalah anak-anak Arjuna, yaitu Abmanyu, Bambang Wilugangga, Sumitra, Gandawerdaya, Gandakusuma, dan Prabakusuma. Khusus Abimanyu, ia adalah korban yang jatuh paling menyedihkan karena lukanya arang kranjang atau seluruh tubuhnya terluka oleh senjata. Lakon yang menggambarkan kematian Abimanyu dianggap sebagai kisah yang paling pedih daripada babak-babak Baratayuda yang lain (Anderson, 2000:81). Babak VII korbannya berasal dari pihak Kurawa, yaitu Nara-nurwenda, Prabu Pratipa, Windandini, dan Burisrawa. Pada Babak VIII, Kurawa kehilangan Bagawan Krepa (yang terbunuh oleh Adipati Karna akibat perselisihan yang terjadi di antara mereka), Wikata, Wikatatleng, dan Dursasana. Kematian Dursasana oleh Werkudara itu sebagai akibat perilaku kurang ajar Dursasana terhadap Drupadi sehingga Werkudara berjanji akan mencincang Dursasana (Ibid., p. 102). Babak IX yang jatuh sebagai korban adalah dari pihak Kurawa, yaitu Durgandasena, Durtajayarata, dan Adipati Karna. Korban yang lain adalah Senjaya (putra Yama-widura) yang memihak Pandawa. Babak $X$ merupakan babak yang menentukan karena babak ini dianggap sebagai babak akhir Perang Baratayuda. Babak ini menceritakan semua korban jatuh dari pihak Kurawa yang dimulai oleh Premeya, Pandita Durna, Prabu Salya, Antisura dan Surabasah (anak Sengkuni), Sengkuni, dan ditutup oleh kematian Duryudana di tangan Werkudara. Dua babak berikutnya adalah babak yang menceritakan pascaperang, tetapi kedua babak itu tidak terlepas dari peristiwa kekerasan. Babak XI yang jatuh sebagai korban adalah keluarga Pandawa yang meliputi Dewi Srikandi, Dewi Wara Sumbadra, Arya Setyaki, Trustajumna, Pancawala, Banowati, Kartamarma, dan Aswatama. Dua orang korban yang terakhir adalah orang-orang yang membuat kerusuhan, khususnya Aswatama yang berusaha menuntut balas atas kematian ayahnya (Zaehner, 1992:132), sedangkan Babak XII yang menjadi korban adalah Sencaka, Prabu Wesiaji (anak Brajamusti), dan Resi Jaladara (Prabu Baladewa). Korban-korban yang jatuh pada masa pasca-Baratayuda merupakan efek kekerasan yang ditimbulkan oleh peristiwa sebelumnya. Kekerasan Baratayuda tidak 
sendirinya padam dengan usainya perang tersebut (Nugroho, 2001:73-83) sebagaimana yang telah dikatakan oleh Geertz (1989:361) bahwa konflik Pandawa melawan Kurawa merupakan konflik yang tidak kunjung berakhir meskipun tampaknya akan diakhiri dengan perang Baratayuda (suatu lakon yang jarang dimainkan di Jawa).

Daftar korban yang panjang itu menunjukkan bahwa peperangan itu merupakan peristiwa yang merugikan, baik bagi pihak yang menang maupun terlebih-lebih pihak yang kalah. Meskipun Kurawa sering digambarkan sebagai pihak yang rakus dan haus kekuasaan (Suseno, 1988:162) atau sebagaimana yang dikatakan Anderson (2000:15) sebagai ksatria-ksatria yang jahat yang menghalalkan segala cara, misalnya dengan tipu muslihat berpesta di Bale Sigala-gala dan permainan dadu (Mulyono, 1983a:95), tetapi bagaimanapun mereka itu tetap saudara Pandawa. Tumpasnya Kurawa dilihat dari sisi Pandawa, maka peran Kresna berada pada posisi pahlawan karena ia menjadi penasihat Pandawa. Namun, dari sisi Kurawa, Kresna adalah orang yang paling jahat dan paling berdosa karena ia yang mengadu domba kedua keluarga Barata tersebut hingga tumpasnya Kurawa sehingga Dewi Gendari mengutuk Kresna dan keluarganya (Yadawa) habis seperti Kurawa. Maka dari itu, lakon Baratayuda dianggap sebagai lakon yang angker dan membahayakan sehingga jarang dipergelarkan karena bisa menimbulkan berbagai malapetaka (Suseno, op. cit. p. 163). Ketika lakon Baratayuda (12 babak di atas) dimainkan pada tahun 1958 di keraton Yogyakarta menimbulkan malapetaka sebagaimana dicatat oleh Sri Mulyono (1982a:232-233). Kekeramatan lakon Baratayuda sebenarnya sudah terjadi pada masa Kakawin Bharatayuddha ditulis pada zaman Raja Jayabaya sebagai kesusastraan ruwat karena karya ini dipakai untuk mengesahkan pembunuhan Hemabhupati oleh sang adik, yaitu Jayabaya. Jayabaya mengidentifikasikan dirinya dengan Arjuna, sedangkan Hemabhupati sebagai Kurawa (Mulyono, 1982a:232). Lakon Baratayuda juga digolongkan sebagai lakon murwakala agar segala sesuatu berjalan dengan baik dan untuk mencegah pelbagai bahaya (Suseno, op. cit. p. 160) sehingga dijadikan lakon yang keramat karena tidak semua orang atau dalang berani untuk mementas-kannya (Pontjosutirto, 1985:116). Selain itu, lakon Baratayuda juga tergolong lakon atau cerita kuna yang disegani karena di dalamnya terkandung aspek mitologi (Sudardi, 2004:144).

Kekeramatan cerita Baratayuda pada intinya adalah suatu pencanangan akan rasa penyesalan yang mendalam karena buah dari perang itu adalah tragika yang tidak hanya menimpa seluruh keluarga Kurawa, tetapi juga Pandawa. Hasil perang memang menunjukkan bahwa Kurawa habis, tetapi Pandawa juga meng-alami hal yang serupa. Ketika mereka menang, maka sebenarnya kemenangan itu hanyalah semu belaka. Pandawa yang berjumlah lima itu melakukan perjalanan ke dunia yang abadi, yakni ketika mereka menuju Gunung Mahameru, mereka meninggal satu-persatu 
yang dimulai oleh Drupadi, Sadewa, Nakula, Arjuna, dan Werkudara (Bima). Kekuatan mereka berkurang ketika mereka mendaki menuju surga karena mereka dibebani oleh banyaknya darah yang sudah mereka tumpahkan (Anderson, op. cit. p. 115). Setelah Baratayuda usai memang tidak ada lakon yang menunjuk-kan adanya perayaan kemenangan yang dilakukan Pandawa. Pada hakikatnya, ketika Pandawa menghabisi Kurawa, mereka sendiri pun habis (Suseno,op. cit. p. 165).

Kematian para Kurawa dan juga sanak saudara Pandawa di dalam lakon Baratayuda merupakan adegan-adegan yang meng-harukan dan sekaligus menyedihkan sehingga pasca-Baratayuda sering diisi dengan cerita carangan (cerita profan) agar perhatian terhadap tragika Baratayuda yang gelap itu bisa dibelokkan (Magnis-Suseno, 1988:166-167). Tragika itulah yang memungkin-kan lakon tersebut ditabukan. Lakon Rubuhan yang menceritakan kematian Duryudana juga ditabukan di Jawa karena bencana dan tragedi yang meliputinya begitu besar (Anderson, op. cit. p. 39).

Kematian Duryudana oleh Werkudara dengan memukul bagian paha dianggap sebagai tindakan yang tidak sportif dan mendapat bantuan dari panakawan sebagai pamong dan pelindung Pandawa (Mulyono, 1982b:57). Namun, ketidaksportifan Werku-dara itu telah dilegitimasikan dengan kutukan Bagawan Maitriya yang dihina oleh Duryudana. Kutukan itu menyatakan bahwa Dur-yudana meskipun sudah sekarat kepalanya akan diinjak-injak, mulutnya tidak akan henti-hentinya dijotos, dan tubuhnya diluluh hingga mati (Sumantri dan Kanti Waluyo, 1999:139) Jadi, tindakan Werkudara dianggap sah karena kutukan itu. Lagi pula, bagian paha Duryudana itu adalah bagian yang lemah menurut Bagawan Maitriya (Mulyono, op. cit. p. 67), sedangkan kematian Sengkuni yang tubuhnya disobek oleh Werkudara melalui dubur dan mulutnya karena paman Duryudana itu banyak melakukan fitnah. Sengkuni ketika dibunuh oleh Werkudara juga sedang menjalani karmanya karena tindakannya setelah kekalahan Pandawa dalam permainan dadu (Mulyono, 1983a:70-72).

Tragika Baratayuda pada hakikatnya telah melahirkan rasa penyesalan yang mendalam. Hal itu terbukti, ketika Yudhistira menolak menjadi raja di Astina dan menyuruh Arjuna untuk naik tahta. Atau ketika Pandawa dan Drupadi pergi ke Mahameru untuk mencari jalan keabadian merupakan simbol bahwa kemenangan yang sudah diraih itu sebenarnya bukanlah kemenangan yang sejati. Kemenangan yang sejati adalah kemenangan yang diperoleh dengan mengalahkan dirinya sendiri, bukan menjadikan orang lain sebagai objek kekalahan. Kemenangan Pandawa dalam Perang Baratayuda itu bukanlah segala-galanya karena Pandawa sama sekali tidak menikmati hasil kekerasan yang telah mereka peroleh sehingga mereka mengakhiri kehidupannya di istana alam (Sumantri dan Kanti Waluyo, op. cit. p. 157164). Hasil yang diperoleh adalah penyesalan yang tidak kunjung pandam. Untuk memadamkan hal itu Pandawa menempuh perjalanan ke Mahameru 
dan perjalanan itu merupakan perjalanan hidup yang sebenarnya untuk meraih kemenangan yang sejati. Kenyataan menunjukkan bahwa kemenangan yang sejati itu tidak mudah untuk diraih. Justru perjalanan itu menggambarkan bahwa sikap dan perilaku mereka tergambarkan melalui kematian-kematian yang oleh Yudhistira dikatakan sebagai buah yang harus dipetik oleh mereka atas segala perbuatannya. Intinya, Drupadi dan keempat saudaranya bukanlah orang yang suci dan lepas dari segala kesalahan dan dosa. Kematian-kematian itu dapat melukiskan bahwa hanya Yudhistira saja yang bisa mukswa (Anderson, op. cit. p. 115) berkat kesucian darahnya yang putih.

Nasib yang dialami Yudhistira itu lebih baik daripada keempat saudaranya adalah berkat darahnya yang berwarna putih. Ia tidak pernah marah, bertengkar, dan menolak permintaan seseorang bagaimanapun sederhananya. Jika para ksatria yang lain itu dicirikan dengan senjata masing-masing, maka ciri Yudhistira adalah pusaka suci yang disebut Kalimasada yang mengandung rahasia agama dan rahasia alam sehingga ia menjadi seorang cendekiawan yang tidak berpamrih dan memerintah kerajaannya dengan keadilan dan keluhuran budi (Ibid., p. 23). Kisah tentang Kalimasada dalam pewayangan Jawa modern menyatakan bahwa Yudhistira yang memiliki Kalimasada itu tidak bisa meninggal dunia dan menjumpai Sunan Kalijaga (sampai abad XVI). Sunan Kalijaga menjelaskan bahwa Kalimasada itu harus diartikan sebagai Kalimatasy-Syahada atau rumusan syahada yang mengandung kalimat: "Tidak ada Tuhan selain Allah dan Muhammad adalah Rasul Allah." Yudhistira yang telah dapat membaca kalimat tersebut bisa menikmati kematiannya dan menemukan ketentraman di surga (Berg, 1985: 50-51; Moertono, 1985:46; dan Poedjo-soebroto, 1978:126-127). Ternyata banyak orang Jawa yang tidak tahu asal-usul kata Kalimasada yang padanannya berasal bahasa Jawa Kuna, Kalimahosyadha, yang artinya јати atau alat sakti yang dahsyat dari Kali. Teks-teks yang disebut Kalimahosyadha itu kalau diucapkan dapat mengakibatkan pembebasan dari rasa kesengsaraan, misalnya memutus siklus reinkarnasi (Berg, 1985:50). Fenomena adanya Kalimahosyadha dan KalimatasySyahada atau kalimat syahadat menunjukkan bahwa orang Jawa membuat suatu ikatan keterkaitan antara dua periode sejarah yang tampaknya memang berbeda, tetapi secara hakiki ada kesamaannya bagi manusia Jawa. Hal itu bisa dilihat dari pengakuan Yudhistira bahwa dirinya telah berabad-abad usianya dan tidak bisa mati karena tidak ada orang yang bisa membaca Kalimasada (Moertono, 1985:46-47).

Masalah kekerasan dan penyesalan juga tampak pada kasus Anoman Obong. Peristiwa Anoman Obong terjadi ketika Anoman berkedudukan sebagai duta dari Rama untuk menengok istrinya di Alengka. Perjalanan Anoman menuju Alengka memang dipenuhi dengan kekerasan, misalnya Anoman menjadi hilang penglihatan-nya ketika ia disuguh buah-buahan oleh 
Swayamprabha, putri raja raksasa (menurut versi Kakawin Ramayana, Anoman dan kawan-kawannya terkena sihir dan tertidur selama satu bulan). Anoman juga mendapat serangan dari seorang raksasa yang menelannya sehingga Anoman merobek perut raksasa tersebut dan jatuh ke laut. Setelah itu, Anoman kembali ditelan oleh raksasa lain yang bernama Wilkataksini (Wikataksini), tetapi Anoman kembali lolos dari bahaya dan berhasil menuju Alengka. Akhirnya, Anoman berhasil menemui Sinta di Taman Argasoka. Sesudah pesan Rama disampai-kan pada Sinta, maka Sinta juga menitipkan pesan untuk Rama melalui Anoman. Anoman kemudian merusak kota Alengka sehingga menimbulkan kemarahan Rahwana. Raja Alengka itu menyuruh untuk menangkap Anoman. Indrajit berhasil menangkap Anoman yang kemudian oleh Rahwana, duta Rama itu dibakar. Wibisana melakukan protes kepada kakaknya bahwa seorang duta adalah kebal. Namun, Rahwana bersikukuh untuk membakar Ano-man hidup-hidup sehingga para raksasa membungkus ekor Anoman dengan bahan-bahan yang mudah terbakar. Anoman dengan ekor yang menyala-nyala, ia menyelamatkan diri yang berlanjut dengan terbakarnya keraton dan seluruh kota (Zoetmulder, 1983:281-283). Peristiwa Anoman Obong sesungguhnya merupakan peristiwa ke-kerasan yang dibalas dengan kekerasan yang berakhir dengan penyesalan Anoman. Anoman melihat karena perilakunya yang merusak itu, banyak raksasa yang tidak bersalah menjadi korban (Sindhunata, 1993:222).

\section{ASKETISME KSATRIA}

Asketisme para ksatria menonjol dilakukan oleh Arjuna yang tercantum dalam teks Kakawin Arjunawiwaha atau lakon Mintaraga (Ciptaning). Selain itu, Yudhistira juga melakukan hal yang sama. Asketisme Arjuna dipertanyakan apakah ia melakukan hal itu hanya didorong untuk memperoleh kebahagiaan dan kekuasaan bagi dirinya sehingga ia tidak menghiraukan orang lain? (Ibid., p. 298). Arjuna yang bertapa di puncak Gunung Himalaya didorong oleh rasa keinginannya untuk membantu kakaknya merebut negeri Astina sehingga tujuan utama yang ingin diraih adalah kesaktian dan senjata untuk memenangkan Perang Baratayuda (Ciptoprawiro, 1986:34). Bertepatan dengan tapa Arjuna itu di kahyangan terjadi huru-hara yang ditimbulkan oleh raja raksasa, Niwatakawaca. Para dewa meminta Dewa Indra untuk mencari manusia sakti yang mampu menghancurkan Niwata-kawaca. Manusia sakti yang menjadi pilihan Indra adalah Arjuna. Indra menyuruh Dewi Supraba untuk menggoda tapa Arjuna. Namun, usaha tersebut menemui kegagalan. Selanjutnya, Indra menemui Arjuna untuk menanyakan tujuan tapanya karena Arjuna itu bertapa dengan menyanding senjata busur, panah, dan pedang. Apakah layak seseorang yang bertapa untuk mencapai kamoksan dengan membawa senjata? (Ibid., p. 35). Pertanyaan ini jelas mengesankan 
sesuatu hal yang paradoks. Orang bertapa itu seharus-nya menjauhi dunia karena pada umumnya orang bertapa bertujuan untuk mencapai kamoksan atau kembali kepada Yang Maha Kuasa dengan predikat yang baik. Arjuna yang membawa senjata di dalam tapanya jelas masih mengacu kepada dunia, bahkan hal itu mengesankan ada unsur kekerasan. Oleh karena itu, Arjuna men-jawab bahwa ia bertapa memang tidak bertujuan untuk mencapai kamoksan sebagaimana banyak dilakukan orang yang bertapa, tetapi ia bertapa untuk memenuhi dharma ksatria dengan memperoleh kesaktian dan senjata agar unggul dalam Perang Baratayuda dan tugas melindungi rakyat. Jawaban Arjuna tersebut sangat meng-gembirakan Indra karena hal itu memang yang diharapkannya (Berg,1985:63). Kemudian, Arjuna mendapat ujian yang terakhir yang dilakukan oleh Dewa Siwa yang datang dalam wujud seorang pemburu. Akhirnya, Arjuna berhasil dan lulus dari ujian itu sehingga tapanya diterima oleh para dewa dan Bathara Siwa memberinya panah sakti Pasopati. Hadiah panah tersebut digunakan Arjuna untuk menghabisi Niwatakawaca sehingga ia dinikahkan dengan Dewi Supraba dan enam bidadari yang lain, yaitu Tilottama, War-siki, Surendra, Gagarmayang, Tunjung Biru, Lengleng Mulat (Sastroamidjojo, 1963:22) dan untuk sementara waktu ia menjadi raja di kahyangan (Berg, 1985:63-64: Ciptoprawiro, 1986:35; bdk. Purwasito, 2002:193-195).

Pemaparan di atas menunjukkan bahwa tujuan tapa Arjuna justru dinilai sangat tepat oleh para dewa. Jika tujuan tapa Arjuna untuk mencari kamoksan, maka para dewa merasa rugi karena harapan mereka terhadap Arjuna adalah untuk memusnahkan Niwatakawaca (Ciptoprawiro, op. cit. p. 85). Selanjutnya cerita kias Arjunawiwaha dapat disimpulkan bahwa di dalamnya terkandung hal-hal yang meliputi tiga pokok pemikiran 1) tujuan hidup manusia adalah untuk mencapai kesempurnaan, atau kamoksan, atau kalepasan; 2) bermacam-macam jalan yang bisa ditempuh untuk memperoleh tujuan tersebut; 3) jika Arjuna dalam hidupnya dapat menjalankan kewajiban ksatrianya dengan baik, maka ia juga bisa mencapai tujuan tersebut; 4) usaha untuk memperoleh tujuan itu tidak lepas dari rahmat Yang Maha Kuasa; dan 5) hubungan dan sembah sujud manusia terhadap Tuhan harus ditempuh dengan jalan lahir dan batin (Ciptoprawiro, op. cit.p. 186).

Pemikiran yang dilontarkan Ciptoprawiro di atas juga pada intinya tidak berbeda dengan yang dikutip oleh Sastroamidjojo (1963:75) yang menyatakan bahwa cerita Arjunawiwaha merupakan proses dari syariat, melalui tarikat, menemukan hakikat, dan mencapai marifat. Syariat tercermin pada peristiwa tapa Arjuna yang digoda oleh para bidadari dan serangan babi yang merupakan penjelmaan raksasa Mukha. Tarikat terkandung pada isi wawancara Resi Padya dengan Arjuna yang mempertinggi mutu pengetahuan keagamaan. Hakikat tampak pada peristiwa pertikaian antara Arjuna dengan Siwa yang menjelma dalam bentuk seorang 
pemburu, sedangkan marifat dicerminkan dengan pengangkatan Arjuna sebagai raja di Suralaya (kahyangan) dengan gelar Raja Kirithin.

Wiryamartana (1993:120) menyatakan bahwa di dalam Kakawin Arjunawiwaha terdapat konsepsi tentang realitas yang meliputi tatarantataran realitas atau tataran alam, yaitu 1) alam niskala adalah tataran tan wadag (tidak kelihatan dan tidak terjangkau oleh indra) atau maya, 2) alam sakalaniskala adalah tataran wadag dan tan wadag (tataran yang berada di antara keduanya), dan 3) alam sakala adalah pengalaman wadag yang indrawi. Pengalaman Arjuna ketika diuji oleh para bidadari, ujian Indra, dan ujian Siwa pada hakikatnya adalah maya atau berada pada alam niskala, sedangkan membunuh Mukha dan Niwatakawaca adalah alam sakalaniskala yang diikuti oleh penobatannya sebagai raja di kahyangan dan diganjar bidadari merupakan alam sakala. Bidadari pada intinya adalah mayakarena yang sejati adalah sakti. Karena kesaktian itulah Arjuna mampu membunuh Niwatakawaca. Untuk memperoleh kesaktian, Arjuna melakukan tapa sebagai suatu sarana sehingga tapa Arjuna memang tidak ditujukan untuk kepentingan meraih moksa atau kesempurnaan diri bersatu dengan Tuhan, lalu mati. Jadi, tapa Arjuna bertujuan untuk mendapatkan kejayaan di dalam perang.

Tapa yang dilakukan Arjuna sesungguhnya adalah tapa yang dilakukan oleh ksatria, bukan tapanya para brahmana, tetapi tujuannya sama, yakni moksa, dengan menjalankan dharma atau kewajiban ksatria. Maka dari itu, Arjuna mengusahakan kekuasaan dan kenikmatan sebagai suatu upaya secara sungguh-sungguh untuk menghayati dunia. Penghayatan terhadap dunia hanyalah main-main untuk menanti datangnya kematian (Wiryamartana, op. cit. p. 123). Jadi, tapa brata Arjuna dalam Arjunawiwaha tidak melukis-kan perkawinan Airlangga seperti yang diduga oleh Berg (1985:65), tetapi langkah persiapan Airlangga dalam menghadapi perang (Zoetmulder, 1983:310; Wiryamartana, 1993:123). Dengan demiki-an, tujuan tapa atau asketisme ksatria berbeda dengan asketisme brahmana yang bermaksud secara langsung meraih moksa. Para ksatria bertapa untuk melakukan dharma ksatria yang selanjutnya dapat meraih moksa juga. Jadi, ada perpaduan antara keyogian dan kesatriaan (Wiryamartana, op. cit. p. 122).

Tampaknya tapa Arjuna dalam cerita Mintaraga atau Begawan Ciptaning, atau Arjunawiwaha dalam masyarakat Jawa agaknya mempunyai pengaruh yang luas dan menjadi model bagi para ksatria karena lakon ini sering dibicarakan banyak orang di samping lakon Dewaruci atau Nawaruci. Laku tapa brata Arjuna sering disejajarkan dengan tapa brata Pangeran Dipanegara dalam Babad Dipanegara yang terlibat Perang Jawa (18251830). Tapa brata Arjuna dan Dipanegara merupakan tapa brata dalam rangka mempersiapkan diri menghadapi perang, yaitu Perang Baratayuda dan Perang Jawa. Penyejajaran itu dilakukan untuk menjelaskan bahwa 
Dipanegara itu dipengaruhi oleh alam pemikiran Jawa dan Islam (Laksono, 1985:57-58; bdk. Carey, 1986:26-27). Di samping itu, cerita Arjuna-wiwaha juga berpengaruh kepada proses pemberian nama salah seorang putra Sri Sultan Hamengku Buwono IX, yang kemudian bernama Herjuno Derpito. Asal-usul nama ini dimulai ketika salah satu pusaka keraton Yogyakarta itu diserahkan kepada Sultan. Wayang Srikandi yang ditemukan secara ajaib di kota Ambarawa. Ketika itu kota tersebut diserang Belanda hingga kota terbakar, tetapi di tengah-tengah puing itu terdapat sebuah rumah yang lolos dari kebakaran itu dan ditemukan wayang yang dimaksud. Pengembalian wayang Srikandi disertai pesan bahwa anak yang akan lahir dalam waktu dekat supaya diberi nama Arjunawiwaha. Menurut Sultan, nama itu kurang enak sebagai nama ketika dipanggil sehingga anak itu diberi nama Herjuno Derpito (Mochtar, 1982:112-113).

Tapa brata ksatria juga dilakukan oleh Yudhistira. Tapa Yudhistira adalah tapa ksatria yang berada pada alam sakala. Yudhistira mengalami ujian yang maha berat ketika ia dan saudara-saudaranya mengalami tipu daya Kurawa dalam sebuah pesta di Bale Sigala-gala yang disusul dengan peristiwa kekalahannya dalam permainan dadu melawan Kurawa. Kekalahan itu mengakibatkan ia dan Drupadi, serta saudara-saudaranya harus menjalani masa pembuangan ke hutan selama 12 tahun dan ditambah dengan satu tahun masa penyamaran (Anderson, op. cit. p. 99-102). Setelah masa pembuangan dan penyamaran itu usai, maka Yudhistira dan saudarasaudaranya menghadap Perang Baratayuda. Perang pada hakikatnya juga bertapa dan Yudhistira adalah tokoh sulung Pandawa yang hanya sedikit menumpahkan darah ketika ia menghadap Prabu Salya. Namun, ia melakukan kebohongan yang tersamar sehubungan dengan berita atau desasdesus yang dicipta-kan oleh Kresna tentang kematian Aswatama. Durna merasa yakin bahwa Yudhistira adalah makhluk yang tidak pernah berbohong sehingga untuk meyakinkan bahwa berita kematian Aswatama tidak benar, ia bertanya kepada Yudhistira, tetapi Yudhistira menjawab dengan samar-samar bahwa yang mati adalah hestitama (nama seekor gajah). Jawaban yang samar diterima oleh Durna sebagai Aswatama sehingga Durna mengalami tekanan batin yang berat. Akhirnya, Durna terbunuh dan seterusnya Kurawa habis. Dosa Yudhistira inilah yang memungkinkan ia berumur ratusan tahun setelah Perang Baratayuda dan tidak menemui jalan kematiannya. Tapa Yudhistira setelah pasca-Baratayuda adalah ketika ia melakukan perjalanan suci ke Mahameru, Drupadi dan keempat saudaranya mengalami kematiannya satu-persatu. Yudhistira tetap teguh menghadapi ujian pertama ini. Kemudian, ketika ia dijemput di pintu surga, Indra melarang Yudhistira membawa anjingnya. Ia menolak masuk surga tanpa diiringi oleh anjingnya yang setia. Yudhistira lulus ujian yang kedua. Yang terakhir, ketika Yudhistira melihat para Kurawa berada di surga dengan segala kehidupan yang mewah dan ia juga melihat para Pandawa dan 
Drupadi berada di neraka, Yudhistira juga menolak disuruh masuk ke surga. Yudhistira lulus juga pada ujian yang terakhir. Tapa brata Yudhistira merupakan tapa brata yang bertujuan untuk mencapai kesempurnaan hidup yang berbeda dengan tapa ksatria yang dilakukan oleh Arjuna.

\section{PELANGGARAN ETIKA}

Pelanggaran etika yang menjadi sebab munculnya tabu pertunjukan wayang kulit berkaitan dengan kasus-kasus Anoman yang dibakar ekornya, Narasoma membunuh mertuanya, Adipati Onje mencurigai Demang Narasoma akan membunuhnya dengan racun, Cakrakusuma melakukan intervensi di Gunungwuled, penggambaran alat kelamin Kiai Wuled yang membesar, dan roh Bhomanarakasura yang marah atas ketidakfairan kemenangan Gatotkaca atas dirinya.

Anoman dalam episode Anoman Duta, ia tertangkap oleh Indrajit dan kemudian atas perintah Rahwana, ia dibakar ekornya. Cerita Ramayana senantiasa menyatakan bahwa pembakaran atas diri Anoman itu pada hakikatnya adalah pembakaran ibu kota Alengka. Jadi, Rahwana membakar sendiri negerinya. Anoman bisa dikategorikan sebagai makhluk setengah dewa karena pada cerita wayang pada umumnya, ia adalah anak Bathara Guru dengan Dewi Anjani. Namun, dalam pewayangan Anoman juga disebut sebagai putra Bathara Bayu (dewa angin), bahkan Bathara Bayu disebut sebagai ayah dari dua protagonis yang sangat kuat dalam lakonlakon wayang, yakni Wrekudara dan Anoman. Sebagai tanda lahir dari ketiga figur dalam hubungan kekerabatan mereka adalah ketiga memiliki Pancanaka (kuku jari yang panjang, tajam, dan kuat. Mereka juga memakai sarung poleng magis dengan warna-warna merah, putih, hitam, dan kuning yang menyimbolkan empat dewa, yaitu Brahma, Guru (Siwa), Wisnu, dan Surya. Maka dari itu, Bayu sebagai ayah Werkudara selalu memihak kepada Pandawa (Anderson, op. cit. p. 66). Hubungan Anoman dengan Werkudara digambarkan bahwa Anoman berkedudukan sebagai saudara tua sehingga Werkudara menghormati Anoman. Pembakaran ekor Anoman atas perintah Rahwana merupakan tindakan yang tidak etis karena Anoman adalah seorang duta yang mempunyai kekebalan diplomatik. Pembakaran ekor Anoman oleh seorang dalang ketika menyelenggarakan pertunjukan wayang kulit di desa Sumingkir juga merupakan perbuatan yang tidak etis karena Anoman adalah penjaga Gunung Slamet dan daerah Banyumas.

Narasoma sebagai seorang ksatria melanggar etika ketika ia bisa menerima Setyawati sebagai istrinya, tetapi ia menempatkan mertuanya sebagai duri dalam daging sehingga ia tidak menyukai Begawan Bagaspati menjadi bagian di dalam keluarganya (Ibid., p. 16). Bagaspati menyadari bahwa menantunya itu tidak menghendaki kehadirannya sehingga ia menyuruh Narasoma untuk membunuhnya dengan memberikan senjata atau 
ajian Candabirawa. Pembunuhan Narasoma terhadap Begawan Bagaspati merupakan pelanggaran etika para ksatria yang harus ditebus dengan nyawanya sendiri (Anderson, 2000:17) di kemudian hari, yakni ketika pecah Perang Baratayuda. Perkawinan seharusnya tidak hanya dipahami sebagai hubungan suami istri saja, tetapi juga relasi antarkeluarga sehingga jika Narasoma bisa bersatu dengan Setyawati, maka seharusnya ia juga bisa menerima dengan ikhlas dan hormat keberadaan mertuanya meskipun ia seorang raksasa sekalipun. Bagaspati meskipun ia seorang raksasa, tetapi ia adalah raksasa pinandita. Artinya, eksistensi seseorang seharusnya jangan dilihat dari bentuk atau sisi luar saja karena hal itu bisa mengelirukan (Wiryamartana, log.cit.). Kecantikan seorang wanita misalnya tidak selalu mencerminkan kecantikan hatinya. Begitu pula dengan ketampanan seorang pria yang tidak selalu tampan hatinya. Baik dan buruk seseorang itu tergantung pada masing-masing. Bagaspati bentuk fisiknya adalah raksasa, tetapi hatinya mencerminkan ksatria yang memiliki keintelektualan yang tinggi sehingga ia disebut begawan. Sebaliknya, Narasoma tampan wajahnya, tetapi hatinya dipenuhi dengan sifat angkuh dan tinggi hati sehingga pada prinsipnya Setyawati sang anak dicintai sepenuh hati dan bapak mertuanya dibenci setengah mati hanya karena berwajah raksasa (Sumantri dan Kanti Waluyo, op. cit. p. 125-127). Jadi, Narasoma bukanlah ksatria sejati. Ia tidak tulus mencintai istrinya. Akibat ketidaktulusan itu, Narasoma harus menuai karmanya dengan ajian candrabirawa (Ibid., p. 130).

Adipati Onje yang berkarakter emosional yang ditonjolkan dalam teks Babad Purbalingga, khususnya yang menyangkut pembunuhan terhadap kedua orang istrinya. Sebelum kasus pem-bunuhan itu terjadi, Adipati Onje mencurigai Demang Narasoma akan membunuhnya melalui racun yang dimasukkan ke dalam nasi. Tradisi meracuni musuh memang sangat dikenal hampir di seluruh daerah Purbalingga. Yang paling menonjol adalah di desa Serayu Larangan dan Serayu Karanganyar. Kebiasaan semacam itu menunjukkan bahwa masyarakat yang hidup di situ dijiwai oleh sikap pengecut karena Purbalingga itu dikenal sebagai daerah Kurawa. Meskipun Adipati Onje bukan asli Purbalingga, tetapi karena ia lahir di Purbalingga (khususnya Onje) agaknya ia terbawa oleh pengaruh ketinggihatian seorang anak raja dan kedudukannya sebagai adipati dan karakter daerah yang ditempati. Hingga sekarang perilaku orang-orang Onje cenderung temperamental dan mudah tersinggung sehingga mudah munculnya konflik.

Cakrakusuma sebagai anak Adipati Onje juga mewarisi karakter ayahnya yang menonjolkan dan mengagungkan keturunan kraton Pajang sehingga orang-orang di lokal merasa inferior dan hormat. Inferioritas masyarakat penduduk Gunungwuled memang dibatasi oleh rasa hormat tadi. Namun, ketika Cakrakusuma mencoba melakukan intervensi terhadap kehidupan penduduk dengan pertunjukan wayang kulitnya, maka inferioritas itu berubah menjadi antipati sehingga ada dua kategori yang diciptakan 
dengan batas Sungai Bawang, yaitu Kiai Wuled tinggal di sebelah timur sebagai simbol tuan rumah atau cikal-bakal, sedangkan Cakra-kusuma berada di sebelah barat sebagai pendatang.

Kiai Wuled adalah tokoh cikal-bakal masyarakat Gunung Wuled. Kata wuled mengisyaratkan adanya sikap yang kukuh terhadap tradisi lama meskipun ia sudah bisa menerima yang baru, yakni agama Islam. Kiai Wuled merasa tersinggung dengan inter-vensi Cakrakusuma dan para pengikutnya sehingga ia marah dan melakukan tiwikrama seperti yang dilakukan oleh Kresna ketika ia dijadikan duta oleh Pandawa untuk berunding dengan Kurawa. Perundingan yang gagal dan disertai tindakan curang Kurawa menyebabkan Kresna marah besar sehingga ia melakukan tiwikrama. Tiwikrama Kiai Wuled menjadikan kaki kiri Kiai Wuled berada pada Gunung Korakan, sedangkan kaki kanan berada di Pegunungan Siringgeng. Kedua gunung itu menunjukkan adanya dua kategori binary opposition. Kaki kiri mengisyaratkan ke-masyhuran, suara riuh-rendah, sarung sabit, atau genta kayu. Intinya Gunung Korakan adalah keberanian, sedangkan Pegunungan Siringgeng mencerminkan rasa takut, atau sikap ragu-ragu karena takut. Dua hal itulah yang menyebabkan Kiai Wuled melakukan tiwikrama. Karena ada tegangan antara berani dengan takut, maka muncul ketegangan lain, yaitu alat kelaminnya yang tegang sehingga membesar seukuran kendil. Besarnya alat kelamin Kiai Wuled itu adalah simbol lingga sebagai lambang kejantanan atau Dewa Siwa (Mulyono, 1983a:121). Ada kemungkinan bahwa Kiai Wuled adalah penganut agama Hindu aliran Siwa yang bersedia memeluk agama Islam. Penonjolan alat kelamin merupakan hal yang tidak etis, apa lagi digambarkan dalam keadaan ereksi yang sangat besar melebihi ukuran yang wajar. Mengapa alat kelamin Kiai Wuled itu dibesarkan? Tampaknya hal itu merupakan upaya untuk menekankan bahwa masalah alat kelamin adalah fital dalam kehidupan manusia. Orang harus menjaga alat kelamin itu dan tidak dipakai secara sembarangan sebagai bentuk bagaimana manusia harus menjaga kehormatannya melalui alat kelaminnya itu. Kehormatan dan keselamatan seseorang memang tergantung pada penggunaan alat kelamin. Jika salah guna, maka bukan kehormatan lagi, atau keselamatan yang diraih, melainkan jatuhnya martabat manusia yang akan diiringi dengan kehancuran.

Bhomanarakasura dianggap sebagai cikal-bakal penduduk Trajumaya, Pasunggingan. Masyarakat percaya bahwa roh Bhoma masih bersemayam di Punden Trujamaya yang berada di sebelah barat. Di sebelah timur punden yang pertama tadi terdapat Punden Damarjati dan selanjutnya di sebelah utara punden yang kedua terdapat Punden Krenceng. Dengan demikian ada segitiga punden di Pasunggingan yang terjadi hubungan saling tarik-menarik di antara ketiganya itu. Punden Trajumaya sebagai cikal-bakal seharusnya berkedudukan sebagai punden utama, tetapi dengan berubahnya orientasi kehidupan masyarakat, maka punden itu kurang mendapat perhatian. Orang 
masa kini cenderung berpaling pada dua punden yang lain yang kedudukannya lebih fungsional. Punden Damarjati adalah punden tempat orang mencari petunjuk sebagai simbol keraton yang dianggap sebagai pusat kebudayaan yang adiluhung. Segala sesuatu yang terkait dengan peradaban, misalnya salah satunya adalah kebijaksanaan, maka orang akan memilih datang ke Punden Damarjati. Punden Krenceng adalah simbol keputren, yaitu tempat tinggal para putri yang memakai berbagai perhiasan yang serba mewah sehingga orang yang datang ke punden tersebut mempunyai orientasi untuk mencari kekayaan. Tarik-menarik di antara ketiga punden akan dimenangkan oleh Punden Damarjati dan Punden Krenceng. Kekalahan Punden Trajumaya merupakan kekalahan Bhoma seperti ketika ia dikalahkan oleh Gatotkaca. Bhoma yang dikenal memiliki ajian Pancasona seperti Rahwana (Sindhunata, op. cit. p. 142) tidak akan mengalami kematian sejati meskipun ia sudah terbunuh berkali-kali. Kematian sejati itu datang ketika pertempurannya melawan Gatotkaca terdapat campur tangan para panakawan. Kemenangan Gatotkaca dianggap sebagai kemenangan yang tidak etis yang sejajar dengan kemenangan Punden Damarjati dan Punden Krenceng.

\section{SIMPULAN}

Makna tabu pertunjukan wayang kulit yang menonjol adalah 1) kekerasan dan penyesalan yang kemudian dijadikan cerita sakral sehingga ditabukan, 2) asketisme ksatria yang dilakukan oleh Arjuna dan Yudhistira (yang berbeda tujuannya, Arjuna bertapa untuk memperoleh kejayaan dalam perang, sementara Yudhistira bermaksud memperoleh kesempurnaan hidup dan kembali kepada asalnya), dan 3) pelanggaran-pelanggaran etika yang menyangkut peristiwa Anoman sebagai duta yang dibakar hidup-hidup, Narasoma yang membunuh mertuanya, Adipati Onje yang secara emosional mencurigai Demang Narasoma akan meracuni dirinya, Raden Cakrakusuma yang melakukan intervensi di Gunungwuled dan Kiai Wuled yang menunjukkan alat kelaminnya yang mem-besar, dan roh Bhomanarakasura yang marah karena kemenangan Gatotkaca itu tidak fair.

\section{DAFTAR RUJUKAN}

Anderson, Benedict R.O'G. 2000. Mitologi dan Toleransi Orang Jawa. Yogyakarta: Qalam.

Berg, C.C. 1985. Penulisan Sejarah Jawa. Jakarta: Bhratara Karya Aksara.

Carey, Peter. 1986. Ekologi Kebudayaan Jawa \& Kitab Kedung Kebo. Jakarta: Pustaka Azet.

Ciptoprawiro, Abdullah. 1986. Filsafat Jawa. Jakarta: Balai Pustaka.

Danandjaja, James. 1985. "Mengumpulkan Folklore Bali Aga di Trunyan," dalam Koentjaraningrat \& Donald D. Emmerson. Aspek Manusia 
dalam Penelitian Masyarakat. Jakarta: Yayasan Obor IndonesiaGramedia.

Geertz, Clifford. 1989. Abangan, Santri, Priyayi dalam Masyarakat Jawa. Jakarta: Pustaka Jaya.

Kartodirdjo, Sartono. 1986. "Suatu Tinjauan Fenemenologis tentang Folklore Jawa," dalam Soedarsono (ed). Kesenian, Bahasa, dan Folklor Jawa. Yogyakarta: Proyek Penelitian dan Pengkajian Kebudayaan Nusantara, Departemen Pendidikan dan Kebudayaan.

Laksono, P.M. 1985. Tradisi dalam Struktur Masyarakat Jawa: Kerajaan dan Pedesaan. Yogyakarta: Gadjah Mada University Press.

Mochtar, Kustiniyati. 1982. "Pak Sultan dari Masa ke Masa," dalam Mohammad Roem, dkk. Tahta untuk Rakyat: Celah-celah Kehidupan Sultan Hamengku Buwono IX. Jakarta: Gramedia.

Moertono,Soemarsaid. 1985. Negara dan Usaha Bina-Negara di Jawa Masa Lampau: Studi tentang Masa Mataram II, Abad XVI sampai XIX. Jakarta: Yayasan Obor Indonesia.

Mulyono, Sri. 1982a. Wayang: Asal-usul, Filsafat, dan Masa Depannya. Jakarta: Gunung Agung.

1982b. Apa dan Siapa Semar. Jakarta: Gunung Agung.

1983a. Wayang dan Karakter Manusia. Jakarta: Gunung Agung. 1983b. Wayang dan Karakter Wanita. Jakarta: Gunung Agung.

Notosusanto, Nugroho. 1978. Masalah Penelitian Sejarah Kontemporer. Jakarta: Idayu.

Nugroho, Akhmad. 2001. "Kekerasan Pasca Baratayuda," dalam Sumijati As. Manusia dan Dinamika Budaya dari Kekerasan sampai Baratayuda. Yogyakarta: Fakultas Sastra UGM-Bigraf Publishing.

Poedjosoebroto. 1978. Wayang Lambang Ajaran Islam. Jakarta: Pradnya Paramita.

Pontjosutirto, Sulardjo. 1985. "Upacara Ruwat di Jawa," dalam Koentjaraningrat. Ritus Peralihan di Indonesia. Jakarta: Balai Pustaka.

Purwasito, Andrik. 2002. Imajeri India: Studi Tanda dalam Wacana. Surakarta: Pustaka Cakra.

Sastroamidjojo, Seno. 1963. Sekelumit Unsur Filosofik Tjeritera Ardjuna Wiwaha. Djakarta: Kinta.

Setyowibowo, Wijanarko. 1990. Membuka Tabir Misteri Tokoh-tokoh Wayang Kurawa. Yogyakarta: Toko Buku SG/SR.

Sindhunata. 1993. Anak Bajang Menggiring Angin. Jakarta: Gramedia Pustaka Utama.

Sumantri, Barnas dan Kanti Waluyo. 1999. Hikmah Abadi Nilai-nilai Tradisional dalam Wayang. Yogyakarta: Pustaka Pelajar.

Suseno, Magnis Franz. 1988. Etika Jawa: Sebuah Analisa Falsafi tentang Kebijaksanaan Hidup Jawa. Jakarta: Gramedia. 
Tjermatjarita. 1958a. Baratajuda Babak Ke-1 (Pendahuluan) Kalabendana Lena. Jogjakarta: Badan Penerbit Kedaulatan Rakjat.

Tjermatjarita. 1958b. Baratajuda Babak Ke-2 (Pendahuluan) Kresna Gugah. Jogjakarta: Badan Penerbit Kedaulatan Rakjat.

Tjermatjarita. 1958c. Baratajuda Babak Ke-3 (Djabelan) Kresna Duta. Jogjakarta: Badan Penerbit Kedaulatan Rakjat.

Tjermatjarita. 1958d. Baratajuda Babak Ke-4 Seta Gugur. Jogjakarta: Badan Penerbit Kedaulatan Rakjat.

Tjermatjarita. 1958e. Baratajuda Babak Ke-5 Bogadenta Gugur. Jogjakarta: Badan Penerbit Kedaulatan Rakjat.

Tjermatjarita. 1958f. Baratajuda Babak Ke-6 Randjapan (Renyuhan). Jogjakarta: Badan Penerbit Kedaulatan Rakjat.

Tjermatjarita. 1958g. Baratajuda Babak Ke-7 Burisrawa Gugur Atau Timpalan. Jogjakarta: Badan Penerbit Kedaulatan Rakjat.

Tjermatjarita. 1958h. Baratajuda Babak Ke-8 Suluhan (Gatutkatja Gugur). Jogjakarta: Badan Penerbit Kedaulatan Rakjat.

Tjermatjarita. 1958i. Baratajuda Babak Ke-9 Karna Tanding. Jogjakarta: Badan Penerbit Kedaulatan Rakjat.

Tjermatjarita. 1958j. Baratajuda Babak Ke-10 Rubuhan (Sujudana Gugur). Jogjakarta: Badan Penerbit Kedaulatan Rakjat.

Tjermatjarita. 1958k. Baratajuda Babak Ke-11 Lahirnya Parikesit. Jogjakarta: Badan Penerbit Kedaulatan Rakjat.

Tjermatjarita. 19581. Baratajuda Babak Ke-12 Djumenengan (Lakon Sesudah Baratajuda). Jogjakarta: Badan Penerbit Kedaulatan Rakjat.

Toeriman. 1984. Wayang Purwa (Silsilah). Jilid 1. Purwokerto: tanpa penerbit.

Wiryamartana, I Kuntara. 1993. "Usaha Refleksi Filosofis dalam Alam Pemikiran Jawa," dalam Bambang Rudianto, dkk. Jelajah Hakikat Pemikiran Timur. Jakarta: Gramedia.

Zaehner, Robert C. 1992. Kebijaksanaan dari Timur: Beberapa Aspek Pemikiran Hinduisme. Jakarta: Gramedia Pustaka Utama.

Zoetmulder, P.J. 1983. Kalangwan: Sastra Jawa Kuno Selayang Pandang. Jakarta: Djambatan. 